\title{
Working Foundations for Teachers' Authority
}

\author{
Pingxia Shen \\ School of Teacher and Administrator Education \\ Shaanxi Normal University \\ Xi'an, China 710062
}

\begin{abstract}
Teachers' authority has an important influence on education and is playing a vital role in the process of education and teaching. The operation of the teachers' authority needs some basis. Teachers' education power is the basis of organization for teachers' authority operation and professional literacy, which is a professional basis, and students' recognition is the social basis.
\end{abstract}

\section{Keywords—teachers' authority; teacher literacy; Student}

\section{INTRODUCTION}

Teachers' authority is the education influence that the education power conferred by the state, society teachers relied on and the recognized, respected and trusted for individual factors, shows thetrust and compliancebetween teachers and students in the teaching process. Teachers' authority is a positive education influence, has positive meaning to maintaining the order of teaching and promoting the development of students and teachers.

Clearing the operation foundation of the teachers' authority is the premise to solve other problems of the teachers' authority. Studying the operation process of it, not only enrich the study of the theory of the teachers' authority problems, also are helpful for people to understand the teachers' authority problem, and more important is to solve the teachers' authority problems existing in the education practice.

\section{EDUCATION POWER - ORGANIZATION BASIS FOR TEACHERS' AUTHORITY OPERATION}

Teachers and students is the two general roles in human society, in order to better play their respective roles.On the one hand, school provides behavior rules in their education activities, although the standardization degree are different, all of it reflects the basic rules of communication between teacher and student. For teachers, thepurpose of communication behavior to students is to promote the development of students, the teacher can't punish students at will; for students, thepurpose of communication behavior to teachers is to aim tostudy and implementation themselves, and any other purposes are not allowed. There should be a harmonious and efficient teaching relationship between teachers and students, it should be regulated those who damage it.[1] On the other hand, the school organizations giving their power corresponding their roles in the school which with a social system assupporting background. Teacher power mainly refers to education power, it is a power that teacher to the student, class and course and other education resources in the school, including power, including the choice of teaching content, the organization of teaching activities and so on. Education power for teacher is primarily a professional power. Compared with other education administrative power, education power embodied in the teaching activities of teachers' education, relatively independence, and just this relatively independent education powers affect students. Compared with all kinds of administrative power, teachers' power are more abstract. This power for teacherare obtainedfor that teacher as a representative of the society and transmitter of culture, acquired it in social culture and stem from traditional education at first, but with the development and advancement of society, and the improvement of the education laws and regulations, teacher power in education more and more from the legal power. Because the education power for different teacher individuals, there is a big difference, this power for teacherare not easy to get effective control in practice. It often suffers violation because of can't get effective protection.

In the discussion of power, Fourakersaid "First of all, I don't think power is being given, not byexchanged, also not be compensated, but by practice, and only exist in action $\cdots \cdot$... Power is not the original sense of maintenance and reproduction of economic relations, but is a kind of relation for power at first.'[2] Education power is the reflection of the relationship between teachers and students interaction. Teachers' education power is the foundation of the teachers' authority operation. Education power represents the guidance of educational, making educatee got aguidance, encouragement and support in direction and content. Students are influenced by teachers' authority and recognized it, it is largely inseparable withthe guidance represented by education power. Education power also means the public order and communicative rationality in the education activityat the same time [3]. In education activities, the educated should be what kind of person, how to get along with others, how to realize the value of oneself and so on, all of this need guiding of education power, meanwhile, education power guaranteed how to get along harmonious, orderly, unity and friendly in the life of educationworld, and maintaining public order together. JinShenghong believed that, educative power is the power of education, it is educational firstly, that is to say, it is a value, is to ask the authentic self-creation and guidanceof educated, it also means the power gave education and educators ability to 
action, and namely itguiding educated ability to selfcreationvaluable.[4] It could concluded that education is necessary rather negative. However, now we alwaysencouragingthe subjectivity and individual independence, and think education power is negative, power was seen as ubiquitous negative restriction in education, power even synonymous with suppress, force and slavery. This understanding make the education power equal to repressive education violence, although we can't denied education violence exist in the education system, it is the distortion and misunderstanding of power that equivalent it with violencesimply without analysis. If there's no need for the education authority, the individual will in the state of no guidance, disorder and conflict, also could mean that the individual is in a confusion state that loss of direction and lack of guidance, then the individual may do whatever they want, let themselves drift, this in turn make the education for another extreme. Education power no longer exists, teacher authority also gone.

\section{PROFESSIONAL QUALITY OF TEACHER- PROFESSIONAL FOUNDATION OF TEACHERS' AUTHORITY OPERATION}

Teachers' professional quality is the focus of contemporary teacher quality, also the professional basis in teacher authority operation. The discretion of teacher authority are inseparable with teacher's professional accomplishment, which isteachers' professional ideals, professional knowledge, and professional ability and so on. A highly professional teacher must have authoritative influence on students.

Admitting the teachers' profession is a professional career is the premise of teachers' professional quality and it is closely connected with teachers' professional development. Teachers' professional development is a process that teacher as a professional staff, with professional knowledge for professional ability, have the professional quality, developing professional ideas, never mature to mature. Professional development for teacher is the process of promoting their own quality and forming professional process. As professional personnel, teacher must have certain professional quality, which is the distinction of professional teacher and laypeople. Professor Ye Lanbelieved that teacher professional structure is made up of teachers' education concept, knowledge structure and ability formation. Education concept is the rational knowledge of education and the phenomenon of education subject, is theconsciously reflect and rational knowledge main body for education reality. Education ideas can be said to be the teacher's world outlook and methodology in the education, it is belong to a higher level of professional structure; Teachers' professional knowledge including the most basic scientific and cultural knowledge and skills, professional knowledge and skills, mainly refers to the teachers' professional knowledge and skills, education discipline knowledge, mainly refers to the knowledge of pedagogy, psychology and so on. It contains both expanding of knowledge and contains the knowledge deepening, including the optimization of knowledge structure at the same time; Teachers' professional ability is the most outstanding external performance of the teachers' comprehensive qualities, generally includes the design of teaching ability, expression ability, education teaching skills, management ability, education studying ability, innovation ability, etc. Teachers' professional ability is the core factor for the teachers' professional evaluation; In addition, the teachers' professional self is also an important part of teachers' professional quality, including the correct understanding of self-image, positive experience of self, the right career motivation, career aspirations and clear understanding of their career, etc. Only there are the needs and consciousness of the self-developmentfor teacher, they are likely to clear what they need, and in what direction and how to development they will be in the future. The formation process of teachers' professional self is the process of teachers' professional life personalized, also theprocess of a good teacher image formation.

Dimensions of teacher's professional accomplishment are not isolated, they are related and interact with each other, and all these factors exist in the teachers' body and make mutual effect. They use the broad mind and noble spirit infect people with a wide range of knowledge, compel people with superb skill, guide people with the spirit of science, enlighten people with their wisdom, and they show the teachers style of new era, won the respect and admiration from the society and the students.

\section{RECOGNITION DEGREE OF STUDENT-THE SOCIAL FOUNDATION OF TEACHERS' AUTHORITY OPERATION}

As the main body of education students, the degree of recognition of teachers is one of the important basis of teachers' authority.On the one hand, recognition of student refers to the students as aneducated, in the face of teachers, with the parents, society, and teachers' expectation, also with the expectations of his own, when teachers can meet his expectation, teachers will approved by the students naturally, their authority will run smoothly.On the other hand, studentrecognition for teacher not confined to meet their expectation, more stem from the process of education embody the concept of education, personality, noble quality, or behavior that earned the respect ofstudents, such as appreciation, thus generating a strong affinity and charisma, win the dependence and recognition of students, which further promote the operation of theteachers' authority.

There used to be a teacher said in his blog, "As a teacher, only when he was accepted by the students, can truly realize their maximum value." China outstanding teacher, excellent head teacher Zhi-gang Liu also said: "The recognitionof student is the highest praise for me". Also has teacher said: "Once teaching qualityof a teacher are popular, a teacher in the classroom come to a successful conclusion, a teachers' teaching get fully affirmed, it also the self-realization and self-gratificationfor teacher". It could be seen from this, most courageous for teacher is the recognition of student.Recognition of students can promote teachers worked hard, and gain professional proficiency better, love their work and be devoted to it. In this sense, it is also a kind of support and interaction for teachers. If students have no recognition, acceptance, support and cooperation for teacher, 
teacher authority will impossible to come into being. In turn, when teachers are recognized, it also will have positive effects on students. There often are such situation, a lot of students like and accept a teacher, so like the subject they teaches; Also has a lot of students, they dislike the subject even tired of learningbecause of hating the teacher. The attitude of student for the advice or request teachers given does not depend on the education content right or wrong, but they whether accept the teacher. Recognition of student is benefit for the operation of the teachers' authority. When students recognized the teacher, can produce trust and dependence, and can produce a kind of psychological tendency of stereotypes: all teachers said are right, is standing on the position of his consideration, is for the sake of him, good for him, then will consciously to improve requirements for themselves, makes every effort to adjust their words and deeds according to the requirements of teacher.[5] The feedback of students promotes teachers better use authority, reasonable use of the teacher authority, in turn, will promote the development of students.

\section{CONCLUSION}

Teachers' education power, teachers' professional literacy and students' recognition are all made up with the operation foundation of the teachers' authority. Only through the integration of the three forces, can teachers operate their authority correctly.

\section{REFERENCES}

[1] Yu Qing-chen. Power relation and interaction between teachers and students [M].Beijing:Beijing Normal University Press,2009:135.

[2] Marshall. Michel - Fouraker:Individual autonomy and education [M].Yu Wei,Li Shan-shan,Translate.Beijing: Beijing Normal University Press,2008:109.

[3] Jin Sheng-hong. Discipline and enlightenment [M].Beijing: Education science press, 2004:189.

[4] Jin Sheng-hong. Discipline and enlightenment [M].Beijing:Education science press, 2004:188.

[5] He Bin.Zero distance teaching: The art ofharmonious relationship between teacher and student [M].Chongqing: Southwest China Normal University Press, 2008:2. 